\title{
Independence of the Judiciary in Tanzania: A Critique
}

\author{
By C. M. Peter and M. K. B. Wambali
}

"The individual looks to the law and to the Courts to right any wrong that he has suffered, and does not take the law into his own hands. It is therefore essential for the efficient running or our judicial system that the judiciary and in assessing a judge the public will have regard not only to his judgments in Court but also as to his way of life. Like Caesar's wife, they must be beyond suspicion."

Sir William Duffus ${ }^{1}$

"There are jobs in our society which can be done by undisciplined people and people whose personal integrity can be called into question; being a Judge or Magistrate is not among them."

Julius K. Nyerere ${ }^{2}$

\section{Introduction}

The Judiciary is one of the three arms of the modern state. The other two are the Executive and the Legislature. Among the main functions of the Judiciary is adjudication of cases, interpreting the law made by the Legislature, and to check abuse of power by the Executive. To be able to function properly and to be effective, the Judiciary must be independent of the other arms of the State and especially the Executive. Therefore, Independence of the Judiciary has developed into one of the most sacred principles since the rise of the bourgeoisie. This principle has evolved together with that of Rule of Law and the Supremacy of the Parliament. ${ }^{3}$

There is a debate on whether the Judiciary should restrict itself to its traditional role of applying the law made elsewhere or it should move out of this cocoon and make legal and policy pronouncements which amohnt to law. Blackstone, the great English jurist is among those who insisted that the Judiciary should merely enunciate or discover the existing law. ${ }^{4}$

1 Duffus, Sir William, "The Judiciary and the Public", Dares Saalam University Law Journal, Volume 3, December, 1971.

2 Nyerere, J. K., Speech to the meeting of Judges and Resident Magistrates held at Arusha on 15th March, 1984. See Daily News (Tanzania 16th march, 1984).

3 For a discussion on these principles see Philips, $O$. H., Constitutional and Administrative Law, London: Sweet and Maxwell, 1973; Manchester, A. H. A, Modern Legal History of England and Wales 1759-1950, London: Butterworts, 1980; and other works on Administrative and Constitutional Law.

4 See Hansbury, H. G., "Blackstone in Retrospect" (1950) 66LOR 318; Blackstone, William Commentaries on the Laws of England, London: S. Sweet, 1836; and also Lord Denning, What Next in the Law, London, Butterworths, 1982 Chapter 3. 
However, the current feelings and thinking trend is that actually judges do make law. Sir Charles Newbold, the President of the now defunct Court of Appeal for East Africa in support of this thinking says "For myself, I consider that a Judge's decision is law because he says it; and not that he only says it because it is law. ${ }^{5}$ The Realist School of Jurisprudence has gone further to assert that the Judiciary is the real source of law. A leading realist Justice Oliver Wendell Holmes of the US Supreme Court declared that

"The prophecies of what the Courts will do in fact and nothing more pretentious are what I mean by Law."16

Another realist John Chipman Gray supports him by treating judge-made law as primary and legislative law and precedent as secondary and materials at the disposal of the judge. In his own words:

"It has been sometimes said that the law is composed of two parts, legislative law and judgemade law, but in truth all law is judge-made law."

This being the case, Judge Jerome Frank, the most flamboyant of all realists concludes that:

"Until a court has given its judgment on the facts no law on the subject is yet in existence. Before that decision the only law available is a lawyer's opinion. That opinion is not actually law but only a guess as to what a court will decide. (1 $^{8}$

The arguments by the realists to a great extent augment the importance of the Judiciary as a source of Law. This is totally in conformity with the concrete reality of the present epoch.

Courts have played a great part in the evolution of legal rules in the Common Law system and this can not be easily ignored. The creativity and contribution of the courts is illustrated by the decision in Donoghue $v$. Stevenson ${ }^{9}$ in negligence and Rylands $v$. Fletcher ${ }^{10}$ in strict liability. We may also recall that in Shaw $v$. DPP ${ }^{11}$ the House of Lords declared that the Judiciary is in fact a legislature which may venture into "unravished remnants" of Common Law where Parliament has not found it wise to enter by way of legislation.

5 Newbold, Sir Charles, "The Role of a Judge as a Policy Maker" Eastern Africa Law Review Volume 2 Numer 2 August, 1969.

6 Holmes, O. W., Collected Papers, 1920 p. 173.

7 Gray, J. C., Nature ans Sources of Law, New York, 1938 p. 125.

8 Frank, J., Law and the Modern Mind, New York: Tudor Publishing Company, 1935.

9 (1932) A.C. 562.

10 (1865), 3 H \& C 774.

11 (1961) WLR 897; (1962) A.C. 220. 


\section{Juridiciary in a Historical Perspective}

The judiciary we have to-day has not always been there. It is a product of protracted class struggles. One of the main demands made by the rising bourgeoisie from the absolute monarch was for an independent judiciary.

This was important because under absolutism, the new rising class had no breathing space. All powers were concentrated in one person - the King. He was the law maker, the administrator of the law and its enforcer. In England this was the situation during the reign of King Henry VIII. It was thus essential to use popular slogans in order to get the support of broad sections of the population. These slogans included "Freedom of Contract", "Freedom of Movement", "Freedom to own Property", etc. At the same time there were demands for Independence of the Judiciary, Separation of Powers, Supremacy of the Parliament and Rule of Law.

These demands were achieved with the 1688 Glorious Bloodless Revolution in England which marked the final victory of the bourgeoisie over feudalism and the assumption of parliament as the most supreme organ of the state.

Crisis within the bourgeois socio-economic system led to the development of Capitalism to its highest stage-Imperialism. ${ }^{12}$ To counteract the tendency of profit to fall the rate of the bourgeoisie had to export capital to the relativelly underdeveloped parts of the world. This explains why Colonialism. Colonies were to provide raw materials, cheap labour and markets for finished goods. With the colonies supporting the metropole capitalism was assured long survival.

With these aims in mind, the colonialists could not export their laws and legal system to the colonies. Slogans like Rule of Law, Independence of the Judiciary or Supremacy of Parliament could at best undermine their purposes and thus they were left behind in the metropolis. Thus in colonies brutality reigned for the sake of capitalism. To cut costs and ensure total obedience colonial administrators acted as magistrates as well. In then Tanganyika, both during the German and British colonial rule, race was the determinant factor in accessibility of legal institutions. Native Courts were for Africans while Magistrate Courts were for non-Africans. ${ }^{13}$ This system existed with few inconsequential modifications throughout the colonial period which ended in December 9 th, 1961.

Independence in 1961 was a legal act in which political power was transferred from the colonial state to the nationalists led by the Tanganyika African National Union (TANU). The Republic in 1962 did not bring substantial changes for it only substituted the Governor-General for the President as the Executive Head of the State.

12 For a thorough treatment of the development of Capitalism to Imperialism see Lenin, V. I., "Imperialism the Highest Stage of Capitalism: A Popular Outline" Selected Works Volume I, Moscow: Progress Publishers, 1976.

13 See Du Bow Justice For the People, Ph. D. Thesis, University of California at Berkeley, 1973. 


\section{Judiciary After Independence}

After Independence steps were taken to separate judicial and administrative functions. During the colonial period District Commissioners acted as Magistrates as well. This changed after Independence. In 1963 the Magistrates'Court Act ${ }^{14}$ was enacted which introduced a three-tier system. The highest court was the High Court under which was the District Court (which included the Resident Magistrates' Court) and down below was the Primary Court. This Act also did away with the colour of litigants as the determining factor in which court a person could sue. The value of the subject-matter thereafter became the pointer in selecting where to institute legal proceedings. Appeals from the High Court lay in the Court of Appeal for Eastern Africa. Appeals to the Privy Council in England ceased after Independence. Other than those changes, the Judiciary remained intact performing the same functions and applying the same colonial laws which were retained through the Judicature and Application of Laws Act. ${ }^{15}$

\section{Party Supremacy}

There were other developments that affected the Judiciary and other state institutions in the Country. Firstly, the country was formally declared a de-jure - One-Party State in $1965 .{ }^{16}$ Secondly, there was a departure form the principle of parliamentary supremacy to Party supremacy. This was a novel invention by Tanzania. It has been noted by lawyers that even in socialist states the party is not supreme. ${ }^{17}$

Party supremacy was officially institutionalised in 1975 by Act number 8 of 1975 which amended section 3 of the Interim Constitution, 1965.

The amendment provided that:

"All political activities in Tanzania shall be conducted by or under the auspicies of the Party"

and further that:

"The functions of all the organs of the State of the United Republic shall be performed under the auspicies of the Party."

This amendment has been incorporated in the 1977 Permanent Constitution of the United Republic of Tanzania. Coincidently Chama Cha Mapinduzi (CCM) has been declared the only political party in Tanzania.

14 Cap. 537 of the Laws of Tanzania.

15 Cap. 453 of the Laws of Tanzania.

16 Vide the Interim Constitution, 1965 Cap. 596.

17 See Ng'Maryo, Eric Sikuyua and Mawalla, J. R. W. S., "Strengthening the Power of the People" A paper presented at the Tanganyika Law Society Seminar on proposed Constitutional Changes held in Dar-es-Salaam in July, 1983. 
Supremacy of the Party over the Executive was explained and emphasized by the former President Nyerere in the following terms:

"For the truth is that it is not the Party which is the instrument of the government. It is the government which is the instrument through which the Party tries to implement the wishes of the people and serve their interests. And the Party has therefore to determine basic principles on which government should act, it has to determine the policies its government will follow. ${ }^{18}$

The effect of this was to shift policy making duty from parliament to the National Executive Committee of the Party (NEC). However, it should be noted that this did not in any way make NEC decisions legal. To have legal force and thus binding on the courts, they still had to pass through the parliament for "rubber-stamping". This point was well made by the late Sir Biron, J. in 1973:

"The fact that NEC made policy did not mean that it followed without saying that whatever came out of it was law. No! Where an important policy matter had been issued without a corresponding parliamentary endorsement by the way of legislation, the courts of law are not bound to enforce it. ${ }^{19}$

Be what it may, there is no doubt that the Party has systematically stripped the Parliament of all its powers. Under Article 63 (4) of the Constitution the Parliament remains a mere committee of the National Conference of the Party as provided by Article 72 (6) of the CCM Constitution.

This background is necessary to enable us to appreciate how the Judiciary operates in this set-up. Is the Judiciary independent in Tanzania? Does it perform its functions smoothly without interference and are its decisions and orders respected? These are some of the questions we shall hereinafter attempt to answer.

\section{Appointments in the Judiciary}

The government and the Party play a vital, if not a decisive role in determing who will man various positions in the Judiciary. This in a way has a bearing on the work of this important institution.

Chapter five of the Constitution provides for the Judiciary which is to be guided by the Constitution or any other law. The appointment of the top brass in the Judiciary is made by the Head of the Executive. Article 118 (2) of the Constitution provides that the Chief Justice will be appointed by the President. The puisne judges are also appointed by the President in consultation with the Chief Justice. The Constitution also provides safe-

18 Nyerere, J. K., "The Party must speak for the People" Uhuru na Maendeleo, Dar-es-Salaam: Oxforr University Press, 1973 p. 30.

19 See the Proceedings of the Judges and Magistrates Conference held in Dar-es-Salaam in May, 1973. 
guards to the judges such as charging their salaries straight from the Consolidated Fund and an elaborate procedure to be followed before a judge can be disciplined or removed. The former President once boasted about these safeguards "The Tanzanian Constitution makes it very difficult indeed for any judge to be dismissed. ${ }^{20}$

However, experience has shown that these safeguards are not all that water-tight. Judges have been transferred from the Judiciary and given other responsibilities in the government service. ${ }^{21}$

The very fact the executive makes apointments has at times tended to make members of the Judiciary subservient to the Executive and the Party. This is indicated by a circular issued by a former Chief Justice sometime back directing that all cases involving Ujamaa Villages should be sent to him directly as, according to the circular, he was the only person with jurisdiction to entertain them.

This circular brought the Chief Justice under fire at the Judges and Magistrates Conference in Dar-Es-Salaam in 1973. At that conference the late Sir Biron, J. categorically asserted that:

"The Chief Justice can not issue circulars ordering members of the Judiciary to abide by political or executive whims ... judges are supposed to act independently of political or executive pressures and thus to dispense justice without fear or favour."

The late Justice of Appeal Yona Mwakasendo made it clear that until parliament enacts law for establishment of Ujamaa Villages judges and magistrates will not heed to the Chief Justice's circular that cases involving Ujamaa Villages be sent to him.

Despite disagreements with brother judges, the former Chief Justice made his support for the Party and the government policy of Ujamaa quite known. He is reported to have urged the Judiciary to identify itself with the policies of the country and to do everything to further the aims of Ujamaa. In his opinion:

"Since Tanzania believed in Ujamaa, then the interest of many people in land cases should override those of some few individuals. The Judiciary could not be used as a tool to oppose Ujamaa ... as citizens and TANU members, the courts are bound to further Ujamaa. $1{ }^{22}$

20 Former President Nyerere's speech to the meeting of Judges and Resident Magistrates held in Arusha on 15th March, 1984. See Daily News (Tanzania), 16th March, 1984.

21 For example Justice Julie Manning was appointed Minister for Justice in 1975; the late Justice of Appeal Yona Mwakasendo, then a Puisne Judge of the High Court was appointed Chief Corporation Counsel of the Tanzania Legal Corporation in 1976; and Justice Patel was appointed Counsellor at the Tanzania High Commission in New Delhi, India in 1978. See Fimbo, G. Mgongo, "The Court of Appeal of the United Republic of Tanzania", A paper presented at Faculty of Law Staff Seminar, University of Dar-es-Salaam on 20th February, 1982.

22 See "Put Ujamaa First" Daily News (Tanzania) 26th September, 1972. 
Professor Rudi James argues that in his dual capacity the Chief Justice created a dilemma to the judges and magistrates who are by the Oath $\mathrm{Act}^{23}$ committed to solve disputes according to the law. ${ }^{24}$

The lower level of the Judiciary is not insulated from the influence of the Executive and the Party either. The Party is involved in the appointment process of the judicial officers. At the Primary Court level, for a person to be appointed Primary Court Magistrate, he has to be recommended by the District Judicial Board which is chaired by the Regional Party Secretary. After considering the candidates, the board sends it recommendations to the Judicial Service Commission which advices the Minister for Justice who makes the appointment. ${ }^{25}$ The Minister for Justice allocates Resident Magistrates to the Judiciary from the list of the newly graduated lawyers form the University of Dar-Es-Salaam who are supposed to undergro one year internship programme with the Attorney-General's Chambers. ${ }^{26}$

Also, assessors who are important in Primary Courts' proceedings are nominated by the Party Branch Executive Committee as provided by the Primary Courts (Assessors) Regulations, 1972. The final selection of the panel is done by the District Executive Committee of the Party.

\section{Harassment of the Judiciary}

Although the Executive and the Party are very instrumental in determining the composition of the Judiciary from the top to the bottom, it does not follow that their wishes are always respected. Where the wishes of these two institutions have been ignored it has led to interference with the work of the Judiciary and at times harassment of the judicial personnel. Sometimes interference and harassment is used to preempt anticipated antiestablishment verdict. A few cases will illustrate the point.

The first reported incident in which a member of the Judiciary was harassed by the Executive took place in Tabora back in 1968. This was in the Case of R.V. Kassella Bantu and others. ${ }^{27}$ In this case a District Magistrate in his judicial capacity released the first accused Joseph Kassella Bantu who was then Member of Parliament for Nzega East Constituency on bail pending trial. The magistrate was detained. ${ }^{28}$

An interesting exchange between the Judiciary and the Executive/Party took place in

23 See The Official Oaths Act, 1962 (Cap. 506).

24 James, $R$. W., "Implementating the Arusha Declaration - The Role of the Legal System" Dar-es-Salaam University Law Journal, Volume 5 December, 1973.

25 See Administration of Justice (Miscellaneous Amendments) Act, 1971 (Act 26 of 1971).

26 For a longer discussion on the Internship Programme which every Tanzanian Lawyer graduating from the University of Dar-es-Salaam must undergo for one year, see $R$ welamira, $M$. $R$. K., "The Tanzania Legal Internship Programme: A New Horizon in Legal Education", Dar-es-Salaam University Law Journal Volume 6 April, 1977.

27 (1969) H.C.D. 170. Since then Joseph Kassella Bantu went into exile and now works and lives in Cologne, Federal Republic of Germany.

28 See The Tanzania Standard, 27th September, 1968. 
Dodoma in 1979. This was in the Case of R.V. Iddi Mtegule. ${ }^{29}$ Before Mpwapwa Primary Court, the respondent Iddi Mtegule stood charge with the offence of disobeying a lawful order contrary to section 124 of the Penal Code. He was alleged to have offered Maandazi (Buns) for sale in disobedience of an order issued by the Mpwapwa Area Commissioner banning the sale and/or consumption of edibles in a bid to prevent the spread of Cholera. The order which was issued on February 19th, 1979 contained a list of all prohibited articles. As Maandazi were not among the prohibited articles, the Primary Court Magistrate acquitted the accused.

The decision angered the Area Commissioner. He wrote a letter to the Magistrate emotionally accusing him of bias and deliberate attempts to thwart efforts of the authorities to stamp out Cholera. He went further than that. He asked the trial Magistrate to explain why he had acquited the accused and threatened to take stern action against the Magistrate. The Magistrate was tough and did not cow down. He retorted immediately that that was in interference with the Independence of the Judiciary. He went on to inform the Area Commissioner that not every accused is suposed to be convicted as in Tanzania an accused person is presumed innocent until the contrary is proved. For the benefit of the Honourable Area Commissioner the Magistrate cited the provisions of the Constitutions relating to the independence of the Judiciary. The matter did not end there. It went to the District Court in revision where the District Magistrate quashed the procedings of the Primary Court, ordered re-arrest of the accused and a retrial by another Magistrate of competent jurisdiction.

At the High Court, Chipeta, J. restored the Primary Court decision commenting that it was his hope and the hope of all those who cherish the rule of law that such flagrant interference with the Independence of the Judiciary will not recur, and when it does, it will receive the appropriate condemnation by the authorities concerned, for if such interference were ignored or allowed to continue, the freedom of the individual whose last bastion is an Independent Judiciary will be imperilled.

At least in the foregoing case the Primary Court Magistrate was brave enough to defend his position when attacked by the Area Commissioner. This was not the case in James Bita v. Iddi Kambi. ${ }^{30}$ In this case which was in Musoma, the District Party Secretary wrote a letter to the District Magistrate informing him that the dispute over allocation of land which was pending in his Court was a political issue and therefore the Party had to be consulted. The Magistrate was therefore asked to shift the dispute from the Court to the Village Council. The poor Magistrate complied with this order. On receipt of the results of the Village Council deliberations on the dispute, he reluctantly wrote a routine judgment abiding by the decision of the Village Council.

The worst interference with the work of the Judiciary was in the Arusha Case of Ally Juu Ya Watu v. Loserian Mollel and Landnai Mining co-operative Society Ltd. ${ }^{31}$ The

29 High Court of Tanzania at Dodoma, Criminal Revision Number I of 1979.

301979 LRT No. 9.

311979 LRT No. 6 
subject of harassment this time was a judge of the High Court Mr. Justice Edward Mwesiumo. In this case there was a tug-of-war over a plot of land between an indivudal and a mining co-operative society. The plaintiff sought an order for eviction of the defendants and damages. Whilst some preliminary chamber applications were being considered the matter was brought to the attention of the Regional Commisioner by the defendants who had chosen to fight the case in and out of court. The Regional Commissioner called the State Attorney and asked the latter to use his good offices to ensure that the case file was withdrawn from the court and transferred for discussion and determination by the Regional Security Committee. The State Attorney rightly advised him that he did not have the power to withdraw case files. Some time later the file was called to Dar-Es-Salaam by the Chief Justice allegedly on instructions of His Excellency the President of the United Republic of Tanzania and no reason was assigned thereto. A messenger was sent from Dar-Es-Salaam to collect the file. The judge was in court hearing other cases when the messenger arrived. His Chambers was ransacked like a criminal suspect's house in an attempt to locate the file. The searchers eventually found the file which was just on the table. The file was returned a few days later undisturbed in an envelope addressed not to the court but to the judge personally. To harass the judge more, the messenger who brought the envelope containing the file told him "I am instructed to tell you that you must sign in this notebook to acknowledge receipt of the case file" ${ }^{32}$

The judge, disgusted by the modus operandi of the trafficking of the case file asked the messenger "why are your people treating me like a primary school child? Even a Primary Court Magistrate deserves more decent treatment than your way of handing me" ${ }^{33}$ Being a mere instrument in the hands of those involved in power politics behind the whole psychological torture of the judge, the poor messenger had nothing to say. Having unnecessarily been subjected to heavy mental torture Justice Mwesiumo withdrew from the case.

\section{Contempt of Court Orders}

For the Judiciary to be effective, it must have the co-operation of other organs of the state especially the Police and the Prisons Department. It is very awkward when the court makes a decision and the executive refuses to enforce it. This happened in the United States of America under President Andrew Jackson. To show displeasure over a decision of the Supreme Court, the President decided to ignore it saying:

"Well, John Marshall (the Chief Justice of the USA) has made his decision, now let him enforce it. $11^{34}$

32 See p. 6 of the Ruling of Mwesiumo, J.

33 Ibid.

34 This incident is cited by Justice Nasoro Mnzavas, J. K. in Ally Lilakwa v. Regional Prison's Officer and Regional Police Commander High Court of Tanzania at Arusha, Miscellaneous Criminal Cause Number 29 of 1979. 
This has happened many times in Tanzania. Court orders have been completely disregarded or ignored by those supposed to enforce them. There are many cases which indicate this tendency.

For example in Sheikh Mohamed Nassoro Abdullah v. the Regional Police Commander Dar-Es-Salaam, ${ }^{35}$ the applicant, a religious leader was arrested at his house at Mabibo in Dar-Es-Salaam and "Whisked away in a landrover to police custody" and later deported to Zanzibar on the orders of the President. This deportation was challenged on the ground that the President has no power under the Deportation Ordinance to deport a person from any part of Tanganyika to Zanzibar and thus by deporting the applicant the President had exceeded his powers. The application was upheld and the order of habeas corpus issued. However, the authorities ignored the Court order and to date the applicant is still restricted in Zanzibar.

This happened also in Lesinoi Ndeinai or Joseph Saleyo Laizer and Masai Lekasi $v$. regional prisons officer and regional police Commander. ${ }^{36}$ In this case the two applicants were arrested by police in August 1979 pursuant to orders of the officer commanding the district. From police they were transferred to prison and no charges were preferred against there. Being naturally desirous of resumption of their liberty, they filed application for habeas corpus. The High Court granted the application and ordered immediate release of the two detainees.

However, the unexpected happened. On stepping outside the courtroom as free men, the two were immediately re-arrested and returned back to prison. The order of the court that they be released as their detention was illegal was totally disobeyed by both the police and prison of ficers.

Similarly, in Ally Lilakwa v. regional prisons officer and regional police Commander ${ }^{37}$ court orders were ignored by the authorities. The point was habeas corpus again. However, before the application could be considered by the Court, the prison officers in Arusha transferred the applicant to Dodoma allegedly on orders from the Prisons Headquarters in Dar-Es-Salaam. This was a calculated move to frustrate implementation of Justice. This was the submission by the applicant's advocate Mr. Mwale. The gravity of the matter is shown by the words of the advocate:

". . judging from what has been transpiring from a number of applications which have been filed in this court it is crystal clear that what the respondents are doing is nothing else but attempts to defy the court's orders and an attempt to deny justice to the applicant ... the respondents were aware of the application and had been duly served with notices of hearing for this morning. It is most surprising that the respondents decided to comply with orders from their superiors in Dar-Es-Salaam instead of obeying orders in this court."

35 High Court of Tanzania at Dar-es-Salaam, Miscellaneous Criminal Cause Number 21 of 1983 (Unreported).

36 High Court of Tanzania at Arusha, Miscellaneous Criminal Cause Number 22 of 1979.

37 High Court of Tanzania at Arusha, Miscellaneous Criminal Cause Number 29 of 1979. 
The counsel continues:

"The acts of the respondents suggests that individual freedom does not exist in Arusha . . the acts of the re spondents are tantamount to saying that there is no rule of law in this country. What the respondents are doing goes counter to the beliefs of His Excellency the President of the United Republic of Tanzania who is one of the staunch defenders of the Rule of Law in this country."

Seeing how helpless the court was in those circumstances and the hopelessness of the situation the counsel concluded:
"We can not at this hour make prayer before this honourable Court because whatever prayer we made and granted in previous applications were defied by the Police in Arusha and their headquarters in Dar-Es-Salaam. We are only praying the administrative action be taken by this superior Court. ${ }^{38}$

Also, in Happy George Washington Maeda v. regional prisons officer Arusha ${ }^{39}$ Jaji Kiongozi Mnzavas ordered the release of the applicant from custody as both his arrest and detention were unlawful. However, on leaving the Judge's Chambers a free citizen, the applicant was set upon by police officers in civilian attire who were waiting for him outside. He was arrested and returned to prison where he was illegally detained.

The worst happened in Edward Mlaki and Liston Matemba v. regional police Commander Kilimanjaro Region and secretary regional Security Committee Kilimanjaro Region. ${ }^{40}$ The Applicants in this case had two saloon cars which they were using as taxicabs seized by the Police. They applied for order of Mandamus so that they are released. What is shocking in this case is the defiance by the two Respondents, the Regional Police Commander and the Secretary of the Regional Security Committee towards the due process of the Court. They refused to accept service of summons from a duly constituted process server of the Court.

This blantant refusal by both respondents depicts the degree of hostility between the Judiciary and other State and Party organs. This greatly worried Justice Mwesiumo who commented that:

"this defiance to the court process by the two highly placed government officials though prima facie directed at this court is in fact directed to the laws of this country and therefore to the Constitution and the Government of this land. It would be definitely cheating oneself that by so doing it is the court which is being flouted but in reality it is tantamount to watering down the whole legal system of the country."

38 See page 1 of the judgement.

39 High Court of Tanzania at Arusha, Miscellaneous Criminal Cause Number 36 of 1979.

40 High Court of Tanzania at Arusha, Miscellaneous Civil Application No. 38 of 1979. 
On the part of the Regional Police Commander, the Judge wondered how such a person who day in day out needs the co-operation of the public is getting witnesses to Court in his duty of maintaining law and order could set such a bad example to others.

Maybe, it is because of being alarmed by the sharpening of the conflict between the judiciary and the other State and Party organs that the Chief Justice Mr. Francis Nyalali, while touring the Kondoa District in 1980 called for frequent meetings between officials of the Police and Judiciary to discuss how best to enforce law and order. ${ }^{41}$

\section{Side-stepping the Judiciary}

Having realised that the Judiciary is not always on its side, there have been attempts by the State to avoid crossing paths with the Courts of Laws. This has been made public by the Executive openly airing its distrust for courts. For example during the crackdown on "racketeers and economic saboteurs" in April, 1983, former head of the Executive Julius Nyerere said:

"We have a problem on what to do with these people. However, we have not yet decided on the course of action ... I ask magistrates to forgive us if we hesitate to take culprits to courts of law. At times racketeers have been taken to courts where they either receive light sentendes or have been set free... In the courts the racketeers could use their ill-gotten money to engage lawyers or use that money to twist the law in their favour ".$^{42}$ (emphasis added)

It should however be noted that this tendency of avoiding courts of law is not peculiar to Tanzania. It has developed with the growth of the bourgeois social and political system. At times because of class and intra-class struggles it is impossible to maintain a purely bourgeois judiciary. Therefore, various methods have been devised to avoid Courts of Law in sensitive issues which may jeopadize the interests of the ruling class. Among these methods are the introduction of "ouster" clauses and resort to administrative tribunals.

Ouster clauses are statutory provisions excluding application for prerogative remedies in the Courts of Law. These clauses thus makes the administration immune from judicial review. Others have called this method as being "judge-proof ". ${ }^{43}$ Those who might think of challenging administrative action are thus effectively disarmed. An example of an ouster clause is section 7 (5) of the Tanzanian Interim Constitution of 1965 which provides that:

41 See Daily News (Tanzania) 25th January, 1980.

42 See Daily News (Tanzania) 6th April, 1983 also quoted in Malingumu Rutashobya, "On Prof essional Misconduct and Legal Ethics: A Lawyer's View“, A paper presented at Tanganyika Law Society Seminar held in January, 1984.

43 See Oluyede, P. A., Administrative Law in East Africa, Dar-es-Salaam, East African Literature Bureau, 1973 p. 195. 
"Where a person has been declared by the Electoral Commission to have been elected President, his election shall not be questioned in any Court."

Ouster clauses take various forms and are related to what are called finality clauses which provide that a certain decision is "final" or "final and conclusive". Where the State thinks fit to oust the jurisdiction of the courts, then it resorts to clauses of this nature.

Administrative tribunals, also sometimes referred to as "Kangaroo Courts" for quick justice are another method used by the State as a substitute to the normal Courts of Law. Again these tribunals are concentrated in the areas classified as sensitive to the economy and thus likely to cause political and social instability. The proceedings of most of these tribunals are held in camera to avoid publicity. Areas covered by tribunals include Land, House Rent, Economic Sabotage, Labour Disputes and so on. These are sensitive areas which must be handled administratively by people in whom the State has total confidence.

Democratic minded citizens who advocate for respect for rule of law have always indicated their dislike for tribunals. One of the most unpopular tribunals was the Anti-Economic Sabotage Tribunal in Tanzania established under the Economic Sabotage (Special Provisions) Act 1983. However, it has been justified by the Executive as a necessary instrument to curb certain economic and social evil. In the words of Nyerere:

"Successive governments in this country have sometimes been forced to pass laws which in practice can be very dangerous for justice ... the recent Economic Sabotage Acts, together with setting up of tribunals could be cited and there may be others. The reason for these laws is known. People can differ about whether or not they are necessary, but it is obvious that those who proposed them, or agree to them, thought that they were necessary and I am among those who saw their importance. $1^{44}$

The Economic Sabotage Act completely excluded jurisdiction of the courts in all offences termed economic sabotage. ${ }^{45}$ This has been interpreted as an indication of lack of

44 Former President Nyerere's speech at the Meeting of Judges and President Magistrates held at Arusha on 15th March, 1984; see Daily News (Tanzania) 16th March, 1984.

45 See Mwanukuzi, P. G. and Mjemmas, G. L., "A Socio-Economic and Legal Critique of the Economic Sabotage (Special Provisions) Act, 1983" A Third Year Compulsory Research Paper, Faculty of Law, University of Dar-es-Salaam, 1984. An editorial note in a new book by the Legal Aid Committee of the Faculty of Law, University of Dar-es-Salaam describes the Economic Sabotage Act in the following terms: "The Economic Sabotage Act, 1983 was a draconian piece of legislation establishing tribunals outside of and parallel to the judicial system of courts. The tribunals had exclusive jurisdiction to try certain existing of fences categorised as reconomic sabotage offenses'. The tribunals were headed by judges and assisted by two laymen, all appointees of the President. They had no security of tenure. Their decision were made by the majority. The accused could not be represented by advocates nor did they have right to bail. Decisions were final; there was no provision for appeal. Rules of evidence under the Evidence Act were set aside and even the rigorous of Criminal Procedure Code on arrest and detention did not apply to the suspects of weconomic sabotage offenses".

See Essays on Law and Society by Legal Aid Committee, Faculty of Law, University of Dar-es-Salaam, Published by Sapoba Bookshop Press Ltd., Kampala, Uganda, 1985. 
confidence in the Judiciary and the Judiciary has not taken it lightly. Judges have at times condemned laws which seek quick decisions at the expense of Justice. ${ }^{46}$

However, mounting criticism and failure to achieve what was anticipated through the tribunals has forced the government to look back to the Judiciary. This has been basically for credibility and search of acceptability among the people. The Economic Sabotage Act has now been repealed and replaced by another Act which allows the High Court to entertain what are categorised as economic crimes. ${ }^{47}$ At the same time the Executive and the Party seems willing now to provide audience and entertain advice from the Judiciary at various forums including lecturing the National Executive Committee (NEC) of the Party on the rule of law. ${ }^{48}$ This indicates the level of crisis the country is undergoing. It is the type of crisis which compels the high handed Executive to see sense in a lot of commonplace and old truths like the need to respect rule of law.

\section{The Contribution of the Judiciary}

The record of the Judiciary in Tanzania, especially the High Court and the Court of Appeal in advocating for individual liberty and rule of law is unassailable. ${ }^{49}$ Though working under extremely complicated political climate, the Judiciary has managed to weather the storm. It has managed to contribute considerably to the development of the law and particularly in interpreting the law in favour of the under-privileged and oppressed sections of the population.

This is clearly established by the various incidents discussed in this paper where the courts of law in appropriate cases have not hesitated to grant applications for habeas corpus. Also, in cases where the State has, without justification detained persons, the courts have awarded heavy damages for false imprisonment. A good example is the case of Feyya Mipawa $v$. The Honourable Attorney-General and Asp Lazaro Kambi. ${ }^{50}$ In this case the plaintiff was claiming special and general damages for trespass to the person because on three occasions he was without lawful causes and for malice prepense, spitefully arrested, detained and prosecuted by or at the instance of the second defendant ant that he suffered loss and injuries as a result. Mapigano, J. awarded general and

46 For example see the Paper by Justice of Appeal Robert H. Kisanga, "The Lawyer and the Society: The Challenge of the Prof essional and the Academic in Tanzania" delivered to the University of Dar-es-Salaam Law Society at the Main Campus on 2nd November, 1983. Also see Kisanga, R. H., "Independence of Judiciary in Tanzania", Indian Bar Review Volume XI Number 2 (1984).

47 The new Act is the Economic and Organised Crime Control Act, 1984. (Act No. 13 of 1984).

48 The Chief Justice of Tanzania Mr. Justice Francis Nyalali presented a paper on the need to respect rule of law titled "M jadala wa Jaji Mkuu Mbele ya Halmashauri Kuu ya Taifa ya CCM" on 17th May, 1984 which was discussed by the Chief Justice of Zanzibar Mr. Justice Augustino Ramadhani to the National Executive Committee (NEC) of the Party. See "NEC Stresses Rule of Law" Daily News (Tanzania) 31st May, 1984.

49 Prof essor Issa G. Shivji terms this characterization of the Judiciary as a "Somewhat charitable view of the Judiciary "; see Shivji, I. G. "The Transformation of the State and the Working People" in Shivji, I. G. (ed.), The State and the Working People in Tanzania, Dakar: Codesria Book Series, 1985 p. 15 footnote 18.

50 High Court of Tanzania at Dar-es-Salaam, Civil Case Number 254 of 1981. See Daily News 19th August, 1983. 
exemplary damages at shillings 400000.00 and special damages at shillings 21452.00 . At one stage in his judgment the judge observed that:

"Indeed, if nothing else, this could be a textbook example of how the powerful can with a total scorn for civil rights and with singleness of purpose cause the machinery of criminal law to operate against a completely innocent subject."

Another area in which the courts have made a remarkable contribution is on the rights of children and women. On children, the courts have developed the "Welfare Principle" and applied it rigorously for the future of children. This principle provides that in case of divorce, custody of the children will be granted to the spouse with the ability of provide a conducive climate for proper upbringing of the children so that they can grow to be responsible citizens. This rule has been very helpful and there are suggestions that it should be extended to cover illegitimate children as well.

On rights of women, the courts have made very progressive decisions and pronouncements. The epoch-making decision is that of the Court of Appeal of Tanzania in Hawa Mohamed v. Ally Sefu. ${ }^{51}$ The bone of contention in this appeal was interpretation of Section 114 of the Law of Marriage Act, 1971. This section provides for division of matrimonial property at divorce. The question was whether domestic housework done by a housewife such as cooking for the husband and the family and caring for the children could be regarded as contributing in the acquisition of property by the family and thus entitling the wife to a share of the family assets at divorce. The High Court judges were divided on this issue. There were two schools of thought on this - liberal and conservative. The liberal school of thought held that domestic duties entitled the wife to a share of the family property. The conservative school held just the contrary. According to this school, for the housewife to be entitled to anything in the family property then she had to make direct financial or material contribution towards the acquisition of the property. ${ }^{52}$

The Court of Appeal upheld the liberal point of view that domestic duties performed by the housewife are important and entitled her to a share in the matrimonial property. The Court observed that:

"Bi.Hawa, the appellant in looking after the matrimonial home, must be regarded as working not only for her current needs but also for her future needs and such future has to be provided

51 Court of Appeal of Tanzania at Dar-es-Salaam, Civil Appeal Number 9 of 1983. For a longer discussion on this case and division of Matrimonial Assets in general see Essays on Law and Society by Legal Aid Committee of the Faculty of Law, University of Dar-es-Salaam published by Sapoba Bookshop Press Ltd., Kampala, Uganda, 1985, Chapter II.

52 The Liberal School is articulated by Makame, J. (as he then was) in Rukia Diwani Konzi V. Abdallah Issa Kihenga High Court of Tanzania at Dar-es-Salaam, Matrimonial Cause Number 6 of 1977 (Unreported). The Conservative School is adopted by Patel, J. in Hamid Amir V. Maimuna Amir 1977 LRT No. 55 and also by Mapigano, $J$. in Zawadi Abdallah v. Ibrahim Iddi High Court of Tanzania at Dar-es-Salaam, Civil Appeal Number 10 of 1980. 
from the matrimonial or family assets jointly acquired during the marriage in keeping with the extent of their contribution."

The decision has been hailed as a landmark pronouncement from the highest court of the land. This is because it recognizes the economic rights of women most of whom being not salaried workers, used to invest their entire youthful and active years in the marriage only to be told at divorce that they have no share in the family assets because they were mere wives who performed "wifely duties" for free..$^{53}$

Yet, others have noted that the pronouncement, without any doubt is one that will affect and will continue to affect many couples or families in the country. It is a matter of public interest and concern. ${ }^{54}$

\section{Conclusion}

There is no doubt that the Judiciary as an organ of the State is there to serve the interests of the ruling class. However, the capitalist system is a living contradiction. While the ruling class would like their interests safeguarded by among other organs, the Judiciary, at the same time they advocate for Independence of Judiciary. This is to render credibility of their system. In an attempt to assert its independence the Judiciary looks "mischevious" in the eyes of those who control the State.

This situation is worse in neo-colonies where the State ist shaky, unstable and very unsure of itself. It is thus easily irritated by any seemingly divergence from the expected behaviour by any of its organs. This explains the ever present suspicion and hostility between the Judiciary and the Executive arm of the State. Therefore, a progressive and pupular Judiciary, manned by principled and honest men will always be operating in a very delicate balance. The interests of the people and those of the State have to be carefully balanced.

53 See Rwezaura, B. A. "Division of Matrimonial Assets under the Tanzania Marriage Law" Verfassung und Recht in Ubersee 17. Jahrgang, 2. Quartal 1984 pp. 177-193.

54 See Ismail, M. A. "Public Interest Litigation" A paper presented at Tanganyika Law Society Seminar held in Dar-es-Salaam in January, 1984. 
in the study. Furthermore, it takes a look at American policy towards Angola and Mozambique as important factors of regional co-operation and conflict.

The conclusion weighs the results and attempts to clarify whether the imposition of sanctions against South Africa in 1985/86 together with other measures indicates a new course in American foreign policy towards Southern Africa.

\title{
Independence of the Judiciary in Tanzania: A Critique
}

\author{
By C. M. Peter and M. K. B. Wambali
}

The authors examine the concept of Independence of the Judiciary from a historical and socio-economic context and then survey the concrete application of this concept in the United Republic of Tanzania.

The authors observe that the concept was used by the rising middle class to rally other sections of the population against the absolute monarch. The moment this was achieved, then the concept remained mere theory. It was particularly ignored purposely in the colonies in order not to sabotage the aim of those ruling the colonies.

Even after independence of the former colonies, the concept was never given its proper place in the state structure. The former colonies paid lip service at best. The authors take the case of Tanzania which is representative of what is taking place in the Third World to show that Independence of the Judiciary does not exist there either in theory or in practice. The Judiciary is in all aspects controlled by the executive arm of the State. The authors note that there are two parallel interests: the interests of the ruling class and those of the people. For a Judiciary to be worth its name it has to say in no uncertain terms where it stands.

\section{Land Privatisation among Kenya's Masai, or the Negation of a Communal legal System}

\section{By Xavier Péron}

This paper analyses the fundamental reasons behind the failure to bring about a land tenure reform amongst a nilotic pastoral people of East Africa: the Kenya Masai. It concerns the so-called "Group-ranches" reform, in the context of the Kenya livestock development project, financed by the World Bank.

The reasons for this failure have until now been wrongly identified in that this project seemed above all to integrate traditional forms of organization, as much social as economic, of the Masai.

The author attempts to explain here that this was not in fact the case, and shows how, on 